\title{
Article \\ Influence of Optimal Intensity Measures Selection in Engineering Demand Parameter of Fixed Jacket Offshore Platform
}

\author{
Sajib Sarker $^{1}\left(\mathbb{D}\right.$, Dookie Kim ${ }^{1, *(\mathbb{D})}$, Md Samdani Azad ${ }^{2}\left(\mathbb{D}\right.$, Chana Sinsabvarodom $^{3}$ and Seongoh Guk $^{1}$ \\ 1 Department of Civil and Environmental Engineering, Kongju National University, Cheonan 31080, Korea; \\ sajibsarker@smail.kongju.ac.kr (S.S.); ai_sog@kongju.ac.kr (S.G.) \\ 2 Department of Civil and Environmental Engineering, Konkuk University, Seoul 05029, Korea; \\ samdaniazad@konkuk.ac.kr \\ 3 Naval Public Work Department, Royal Thai Navy, Bangkok 10600, Thailand; chana.si@navy.mi.th \\ * Correspondence: kim2kie@kongju.ac.kr; Tel.: +82-41-521-9315
}

Citation: Sarker, S.; Kim, D.; Azad, M.S.; Sinsabvarodom, C.; Guk, S. Influence of Optimal Intensity Measures Selection in Engineering Demand Parameter of Fixed Jacket Offshore Platform. Appl. Sci. 2021, 11, 10745. https://doi.org/10.3390/ app112210745

Academic Editor: Jong Wan $\mathrm{Hu}$

Received: 13 October 2021

Accepted: 11 November 2021

Published: 14 November 2021

Publisher's Note: MDPI stays neutral with regard to jurisdictional claims in published maps and institutional affiliations.

Copyright: (c) 2021 by the authors. Licensee MDPI, Basel, Switzerland. This article is an open access article distributed under the terms and conditions of the Creative Commons Attribution (CC BY) license (https:/ / creativecommons.org/licenses/by/ $4.0 /)$

\begin{abstract}
This research identifies the significant optimal intensity measures (IM) for seismic performance assessments of the fixed offshore jacket platforms. A four-legged jacket platform for the oil and gas operation is deployed to investigate the seismic performance. The jacket platform is applied with nonlinearly modeled using finite element (FE) software OpenSees. A total of 80 ground motions and 21 different IMs are incorporated for numerical analyses. Nonlinear time-history analyses are performed to obtain the jacket structure's engineering demand parameters (EDP): peak acceleration and displacement at the top of the structure. Four important statistical parameters: practicality, efficiency, proficiency, and coefficient of determination, are then calculated to find the significant IMs for seismic performance of the jacket structure. The results show that acceleration-related IMs: effective design acceleration (EDA), A95 parameter, and peak ground acceleration (PGA) are optimal IMs, and the acceleration-related IMs have good agreements with the acceleration-related EDP.
\end{abstract}

Keywords: jacket platform; intensity measure; OpenSees; time history analysis

\section{Introduction}

Jacket structures are commonly employed for several purposes in the offshore industries, especially in petroleum exploration, offshore wind turbines support structures, etc. The number of offshore structures has been remarkably progressing especially in the field of renewable energy. The legs of the jacket structure are physically fixed to the seabed with the deep foundation. The design of jacket structures typically takes into account the effect of the fatigue degradation under the wind and wave conditions [1-3]. In severe conditions, a jacket structure can experience tsunami and induced earthquake, which are raised concerns for seismic performance evaluation of jacket structures [4]. Seismic design codes and relevant literature commonly use peak ground acceleration (PGA) or spectral acceleration $\left(S_{a}\right)$ as the seismic intensity measure (IM) for probabilistic assessments and risk analysis [5-8]. It is essential to identify the optimal IM that adequately correlates with the structural response to establish a perfect relationship between structural response and IM [9]. There are several studies that explained the correlation between seismic IMs and seismic responses of buildings [10-12], bridge structures [13-17], nuclear power plant structures [18,19], pipelines [20,21], dams [22,23], tunnels [24], and storage tanks [25]. Babaei et al. $[26,27]$ tried to find the best pair of IM-EDP for jacket structures. They found velocityrelated IM is more significant. However, velocity-related IMs, i.e., Housner intensity (HI) and velocity spectrum intensity (VSI), are related to the damping ratio. In seismic design guidelines, the considered damping ratio is five percent of critical damping, which is not established yet for offshore jacket structures. This demonstrates the need to investigate and identify IMs that are not related with the damping ratio. In addition, they did not consider 
any specific target spectrum to ground motions that is necessary for seismic assessment for certain sites. The recent studies on seismic assessments of jacket platforms investigated reliability against seismic and wave loading [28], dynamic characteristics under seismic loads [29], ground motion's sample size effect on fragility [30], seismic hazard assessments [31], development of multi-modal pushover procedure [32], seismic performance by endurance time method [33], and seismic fragility assessments [34]. Some recent studies illustrated the application of system survival signature [35] and reliability-based optimization [36]. Furthermore, offshore jacket structures contain a larger top mass, making the structure sensitive to inertia force related to acceleration. So, the studies on the ground motion's intensity and its influence remains underrated and needs more investigation. This illustrates the importance to consider more IM parameters for site-specific for better accuracy in seismic assessments.

This study aims to identify the significant IMs based on two EDP: peak acceleration and peak displacement. The significant IM is useful to develop probabilistic seismic demand models (PSDMs) of the jacket structure. A set of 21 IMs is used for the analysis. The nonlinear numerical modeling of the jacket platform is developed in OpenSees. A set of 80 ground motion records that contain a wide range of amplitudes, magnitudes, epicentral distances, significant durations, and predominant periods, frequency contents are employed to perform nonlinear time-history analyses of the jacket platform. Significant IMs are determined based on statistical indicators of PSDMs: practicality, efficiency, proficiency, and coefficient of determination. Finally, a set of significant IMs for the jacket structure is advised.

\section{Methodology}

\subsection{Description of Model}

The selected fixed jacket offshore platform for seismic investigation is four-storied with a total mass of 2500 tons applied at the upper joints of the jacket frame. Along with structural components, the platform includes non-structural components such as stiffeners, centralizers, pump caissons, flooding systems, etc. Only the major structural elements are included in the analysis model. This platform was designed and analyzed based on the recommendations of API RP2A-WSD [37]. The physical configuration of the offshore platform is illustrated in Figure 1. In this research, the total height of the jacket platform is $68.58 \mathrm{~m}$, whereas the platform has been designed for a shallow water depth of approximately $65.53 \mathrm{~m}$. The plan of the jacket is square shaped with a top dimension is 8 by $8 \mathrm{~m}$, which extends and becomes 21.76 by $21.76 \mathrm{~m}$ at the mud line. The structural damping is adopted as $2 \%$ [38] of critical damping. The jacket's horizontal bracings are frame elements rigidly connected at the ends. The vertical bracings are provided as Kbracings to reduce buckling and to transmit more stiffness. The joints in the platform are assumed to be rigid joints. For the purpose of simulating the response of pile and jacket member elements, nonlinear beam-column elements with distributed plasticity whose analytical formulation is on the basis of flexibility method with or without iteration are used. The fiber discretization approach has been utilized for modeling the cross section of pile and jacket elements. The general geometric configuration of a fiber cross section is divided into several tiny components with various simple shapes such as square, rectangle, and triangle. The feasibility of creating a cross section of member with these subregion components provides appropriate flexibility in definition of sections composed of different materials. The geometric features considered for each of the fibers are the local $x$ and $y$ coordinates of fibers and their area. The continuity equation of the section is computed on the basis of the stress-strain relationships of the material used. The assumed material for the fibers is considered uniaxially and the strain in each fiber is calculated based on the strain at centroid strain and curvatures at the sections, considering Bernoulli's assumption that plane sections remain plane and normal to element axis after bending. An example of a section comprising different types of materials is the leg element of the jacket with the pile element located inside it. In some cases, the space between the leg and pile is filled with 
grout. To capture the nonlinear response of the jacket platform, nonlinear beam-column elements with distributed plasticity are used. The fiber discretization approach is employed for modeling the cross section local elements. The general geometric configuration of a fiber cross section can be found in Mazzoni et al. [39]. The continuity equation of the section is derived based on the stress-strain relationships of the material used. The assumed material for the fibers is considered uniaxial and the strain in each fiber is computed based on the strain at centroid strain and curvatures at the sections. This formulation is based on Bernoulli's assumption that plane sections remain plane and normal to element axis after bending. The force-based nonlinear beam-column elements along with fiber approach is used to develop the model. The jacket foundation is designed for fixed support conditions. The nonlinear dynamic analysis of the model frame structure is carried out using OpenSees. The structural members comprised of 11 section members as listed in Table 1, whereas the schematic diagram of a cross-section is illustrated in Figure 1e.

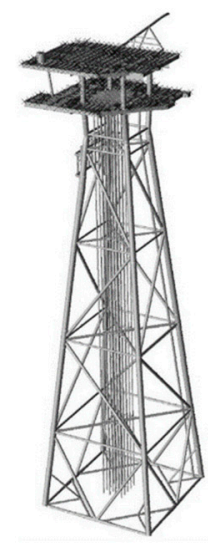

(a)

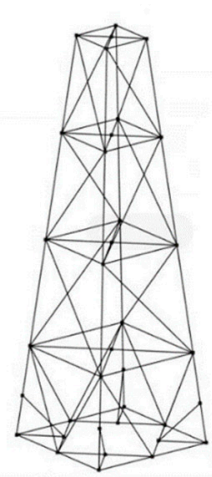

(b)

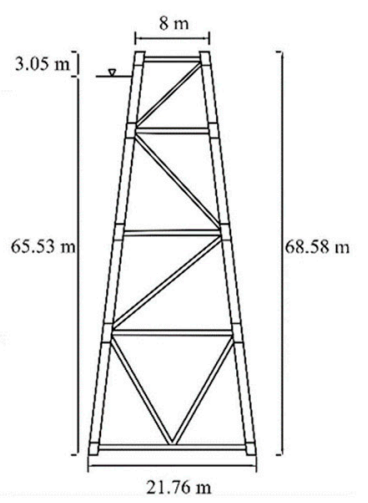

(c)

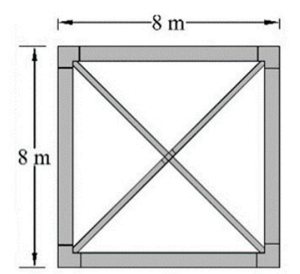

(d)

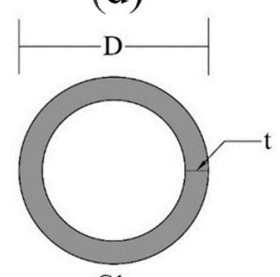

(e)

Figure 1. Fixed jacket offshore platform schematic views (a) Jacket platform from Azad et al. [40]; (b) 3D view of OpenSees model; (c) 2D view (elevation); (d) Top view; (e) Cross section of members.

Table 1. Specifications of structural members of the offshore platform [41].

\begin{tabular}{cccc}
\hline Group & Element Numbers & Outside Diameter, D (m) & Thickness, $\mathbf{t}(\mathbf{m})$ \\
\hline G1 & 1 to 20 & 1.067 & 0.038 \\
G2 & 21 to 28 & 0.457 & 0.010 \\
G3 & 29 to 32 & 0.406 & 0.013 \\
G4 & 33 to 44 & 0.356 & 0.010 \\
G5 & 45 to 52 & 0.457 & 0.013 \\
G6 & 53 to $60 ; 117$ to 120 & 0.356 & 0.013 \\
G7 & 61 to 68 & 0.406 & 0.016 \\
G8 & 69 to 72 & 0.324 & 0.010 \\
G9 & 73 to $80 ; 85$ to 92 & 0.559 & 0.013 \\
G10 & 81 to 84 & 0.559 & 0.019 \\
G11 & 93 to 116 & 0.610 & 0.025 \\
\hline
\end{tabular}

\subsection{Validation of the Model}

Pushover analysis is incorporated to establish the nonlinear force-displacement relationship of the jacket platform. Pushover analysis can be performed following: force control and displacement control methodology. An incremental triangular load pattern is applied, and the load increment is continued till the collapse occurs. Figure 2 illustrates the pushover curve obtained from the nonlinear analysis for the model that has good agreement with the results of Azad et al. [40]. The fundamental frequency of the structure is $0.68 \mathrm{~Hz}$, which matches with the free vibration analysis of Punurai et al. [41]. 


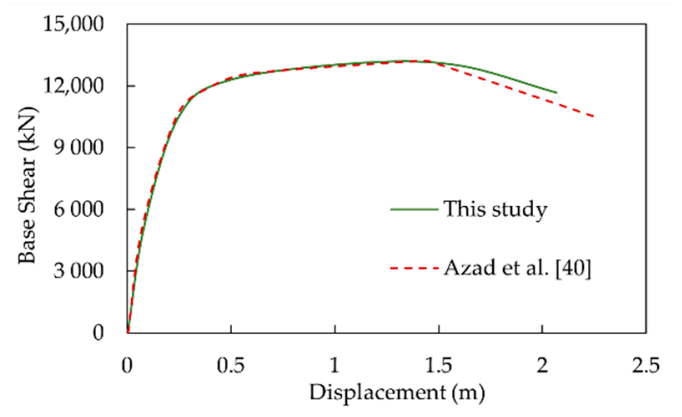

Figure 2. Pushover curve of the model.

\subsection{Ground Motion Selection}

For proper consideration of uncertainties in probabilistic seismic demand analysis, a large number of motion records need to be implemented. The target spectrum is adopted from Nour El-Din and Kim [42]. A set of 80 ground motion records are obtained from the PEER ground motion database [43], considering the target spectrum. The response spectra of ground motions are illustrated in Figure 3.

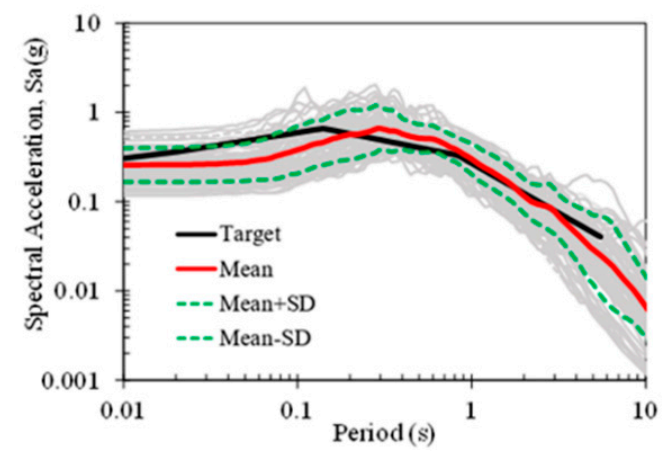

Figure 3. Response spectra of listed ground motions.

\subsection{Finite Element Responses from OpenSees Software}

After the selection of ground motion, nonlinear time history analysis of the FEM model is performed to obtain the responses of the structure. In this research, two responses; peak acceleration and peak displacement are considered as demand parameters. Figure 4 illustrates the overview of obtaining responses of the structure. In this figure, one ground motion (PGA $0.15 \mathrm{~g}$ ) is incorporated with the model to obtain the acceleration and displacement of the top of the structure, whose peak values are $1.509 \mathrm{~g}$ and $0.015 \mathrm{~m}$, respectively.

\subsection{Intensity Measures Selection}

IM represents the characteristics of a seismic ground motion. In general, it can be classified into two categories: (1) structure-based IMs, which integrate structural characteristics into intensity measures, and (2) structure-independent IMs, which only consider the features of ground motions. Based on some other parameters, IMs can be further categorized into various groups such as displacement-related, velocity-related, acceleration-related, and time-related. A total of 21 different IMs is considered in this study and are summarized in Table 2. An illustration of $21 \mathrm{IM}$ parameters of a ground motion is provided in Appendix A. A ground motion is characterized by its amplitude, frequency content, and duration [44] Some reflect only one of these features, while others describe two or three. Peak values like PGA, PGV, and PGD consider only the amplitude of a ground motion, whereas CAV reflects amplitude and duration. Arias Intensity and RMS of acceleration, velocity, and displacement depict all three features, while spectrum acceleration represents amplitude and frequency content features. 


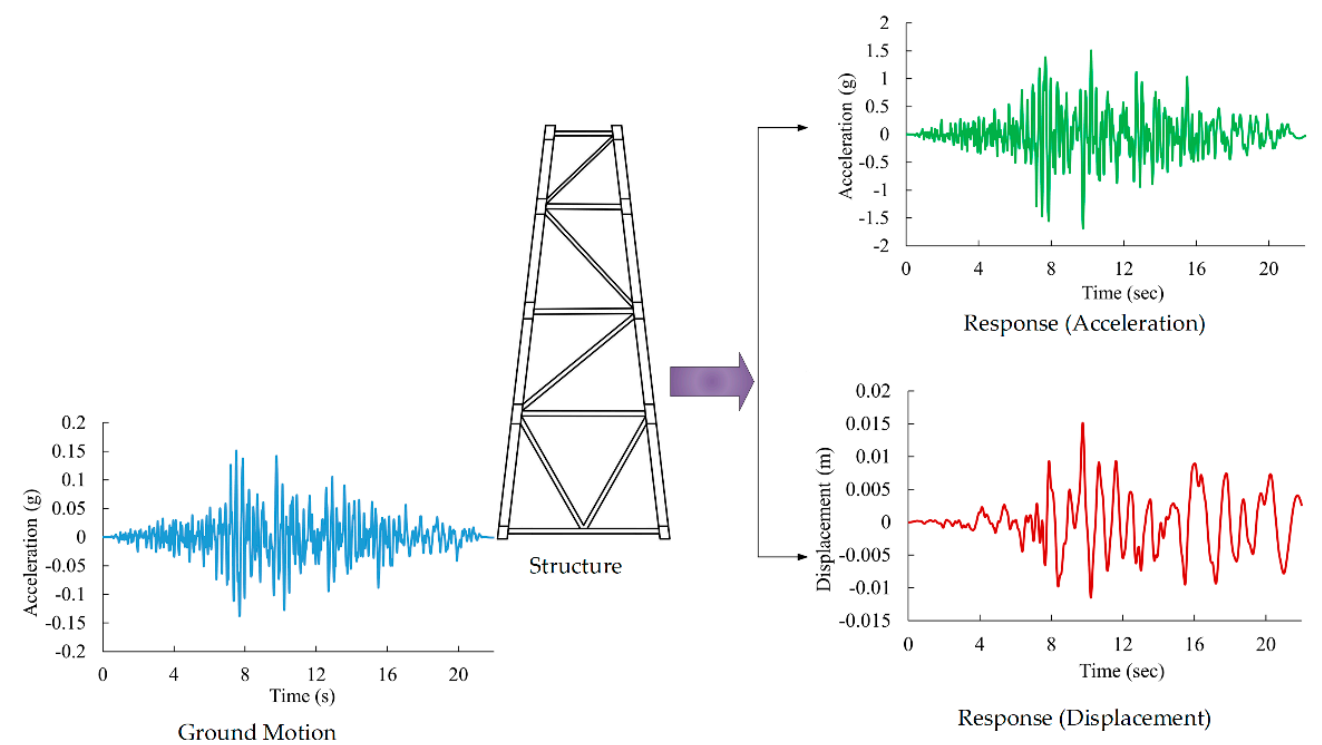

Figure 4. Overview of obtaining responses of model.

Table 2. Lists of considered Intensity Measures.

\begin{tabular}{|c|c|c|c|c|}
\hline IM & Description & Definition & Units & References \\
\hline \multicolumn{5}{|c|}{ Structure-Independent } \\
\hline \multicolumn{5}{|c|}{ Acceleration-Related } \\
\hline PGA & Peak Ground Acceleration & $\operatorname{Max}|a(t)|, a(t)$ is acc. time history & $\mathrm{g}$ & Kramer [44] \\
\hline CAV & $\begin{array}{l}\text { Cumulative Absolute } \\
\text { Velocity }\end{array}$ & $\int_{0}^{t_{\text {tot }}} a(t) d t, t_{\text {tot }}$ is total duration & $\mathrm{cm} / \mathrm{s}$ & Reed and Kassawara [45] \\
\hline $\mathrm{I}_{\mathrm{a}}$ & Arias Intensity & $(\pi / 2 g) \cdot \int_{0}^{t_{\text {tot }}} a^{2}(t) d t$ & $\mathrm{~m} / \mathrm{s}$ & Arias [46] \\
\hline $\mathrm{I}_{\mathrm{C}}$ & Characteristic Intensity & $\left(\mathrm{A}_{\mathrm{rms}}\right)^{3 / 2} \sqrt{t_{t o t}}$ & & Park et al. [47] \\
\hline $\mathrm{A}_{\mathrm{rms}}$ & $\begin{array}{l}\text { Root-Mean Square of } \\
\text { Acceleration }\end{array}$ & $\sqrt{\frac{1}{t_{t o t}} \int_{0}^{t_{t o t}} a^{2}(t) d t}$ & $\mathrm{~g}$ & Housner and Jennings [48] \\
\hline SMA & $\begin{array}{l}\text { Sustained Maximum } \\
\text { Acceleration }\end{array}$ & Third largest peak in $a(t)$ & $\mathrm{g}$ & Nuttli [49] \\
\hline EDA & Effective Design Acceleration & $\begin{array}{l}\text { Peak acc. after filtering out frequencies } \\
\text { beyond } 9 \mathrm{~Hz} \text {. }\end{array}$ & $\mathrm{g}$ & Reed and Kassawara [45] \\
\hline A95 & A95 parameter & $\begin{array}{l}\text { Acc. level below which } 95 \% \text { of the total } \\
\text { Arias Intensity is contained }\end{array}$ & $\mathrm{g}$ & Sarma and Yang [50] \\
\hline \multicolumn{5}{|c|}{ Velocity-Related } \\
\hline PGV & Peak Ground Velocity & $\operatorname{Max}|v(t)|, v(t)$ is vel. time history & $\mathrm{cm} / \mathrm{s}$ & Kramer [44] \\
\hline $\mathrm{V}_{\text {rms }}$ & $\begin{array}{l}\text { Root-Mean Square of } \\
\text { Velocity }\end{array}$ & $\sqrt{\frac{1}{t_{t o t}} \int_{0}^{t_{t o t}} v^{2}(t) d t}$ & $\mathrm{~cm} / \mathrm{s}$ & Housner and Jennings [48] \\
\hline SED & Specific Energy Density & $\int_{0}^{t_{\text {tot }}} v^{2}(t) d t$ & $\mathrm{~cm}^{2} / \mathrm{s}$ & \\
\hline SMV & Sustained Maximum Velocity & Third largest peak in $v(t)$ & $\mathrm{cm} / \mathrm{s}$ & Nuttli [49] \\
\hline \multicolumn{5}{|c|}{ Displacement-Related } \\
\hline PGD & Peak Ground Displacement & $\operatorname{Max}|u(t)|, u(t)$ is disp. time history & $\mathrm{cm}$ & Kramer [44] \\
\hline $\mathrm{D}_{\mathrm{rms}}$ & $\begin{array}{l}\text { Root-Mean Square of } \\
\text { Displacement }\end{array}$ & $\sqrt{\frac{1}{t_{\text {tot }}} \int_{0}^{t_{\text {tot }}} u^{2}(t) d t}$ & $\mathrm{~cm}$ & Housner and Jennings [48] \\
\hline
\end{tabular}


Table 2. Cont.

\begin{tabular}{|c|c|c|c|c|}
\hline IM & Description & Definition & Units & References \\
\hline \multicolumn{5}{|c|}{ Time-Related } \\
\hline $\mathrm{V} / \mathrm{A}$ & Peak vel./acc. ratio & PGV/PGA & s & Kramer [44] \\
\hline \multicolumn{5}{|c|}{ Structure-Based } \\
\hline \multicolumn{5}{|c|}{ Acceleration-Related } \\
\hline ASI & $\begin{array}{l}\text { Acceleration Spectrum } \\
\text { Intensity }\end{array}$ & $\int_{0.1}^{0.5} S_{a}(\xi=5 \%, T) d T$ & $g^{*} s$ & Von Thun et al. [51] \\
\hline$S_{a}\left(T_{1}\right)$ & Spectrum Acceleration & $\begin{array}{l}\text { Spectrum Acceleration at the } \\
\text { first-natural period, } T_{1}\end{array}$ & $\mathrm{~g}$ & \\
\hline \multicolumn{5}{|c|}{ Velocity-Related } \\
\hline$S_{v}\left(T_{1}\right)$ & Spectrum Velocity & $\begin{array}{l}\text { Spectrum velocity at the first-natural } \\
\text { period, } T_{1}\end{array}$ & $\mathrm{~cm} / \mathrm{s}$ & \\
\hline $\mathrm{HI}$ & Housner Intensity & $\int_{0}^{2.5} P S_{v}(\xi=5 \%, T) d T$ & $\mathrm{~cm}$ & Housner [52] \\
\hline VSI & Velocity Spectrum Intensity & $\int_{0.1}^{2.5} S_{v}(\xi=5 \%, T) d T$ & $\mathrm{~cm}$ & Von Thun et al. [51] \\
\hline \multicolumn{5}{|c|}{ Displacement-Related } \\
\hline$S_{d}\left(T_{1}\right)$ & Spectrum Displacement & $\begin{array}{l}\text { Spectrum displacement at the } \\
\text { first-natural period, } T_{1}\end{array}$ & $\mathrm{~cm}$ & \\
\hline
\end{tabular}

\section{Probabilistic Seismic Demand Model}

Performance-Based Earthquake Engineering (PBEE) delineates the quantitative ways to achieve specific predefined performance level earthquake intensity. Pacific Earthquake Engineering Research (PEER) Center has evolved a probabilistic framework for performance-oriented design and evaluation. One of the fundamental components of the PBEE framework is a probabilistic seismic demand model (PSDM).

A PSDM represents the statistical relationship between responses on a structure or its components and the ground motion IM. The pioneering work by Cornell et al. [53] demonstrated that conditional PSDMs could be modeled using a lognormal distribution.

The relationship between the median of seismic demands, $S_{D}$, and seismic IM can be expressed in a power function.

$$
S_{D}=a \mathrm{IM}^{b}
$$

where $a$ and $b$ are the regression coefficients. This expression can be rearranged in forms of linear regression as follows:

$$
\ln \left(S_{D}\right)=\ln (a)+b^{*} \ln (\mathrm{IM})
$$

where constant $\ln (a)$ is the vertical intercept and $b$ is the slope. Output data for the regression analysis are originated from performing nonlinear time history analyses. Peak demands $\left(d_{i}\right)$ are plotted against the IM to estimate the regression parameters and the dispersion, $\beta_{D \mid I M}$.

The following expression is used to estimate the dispersion, where $d_{i}$ is the $i$ th structural demand and $N$ is the total number of ground motions.

$$
\beta_{D \mid \mathrm{IM}}=\sqrt{\sum_{i=1}^{N} \frac{\left[\ln \left(d_{i}\right)-\ln \left(S_{D}\right)\right]^{2}}{N-2}}
$$

\section{Characteristics of Optimal IM}

For the fundamental objective of this research, nonlinear time history analysis of the $3 \mathrm{D}$ finite element model of the offshore structure is performed with 80 ground motions to obtain EDPs. A total of 21 different IMs of ground motion are selected to correlate with 
the EDPs of the structure by performing linear regression analysis. Figure 5 illustrates the overview of the methodology of optimal PSDM evaluation [26].

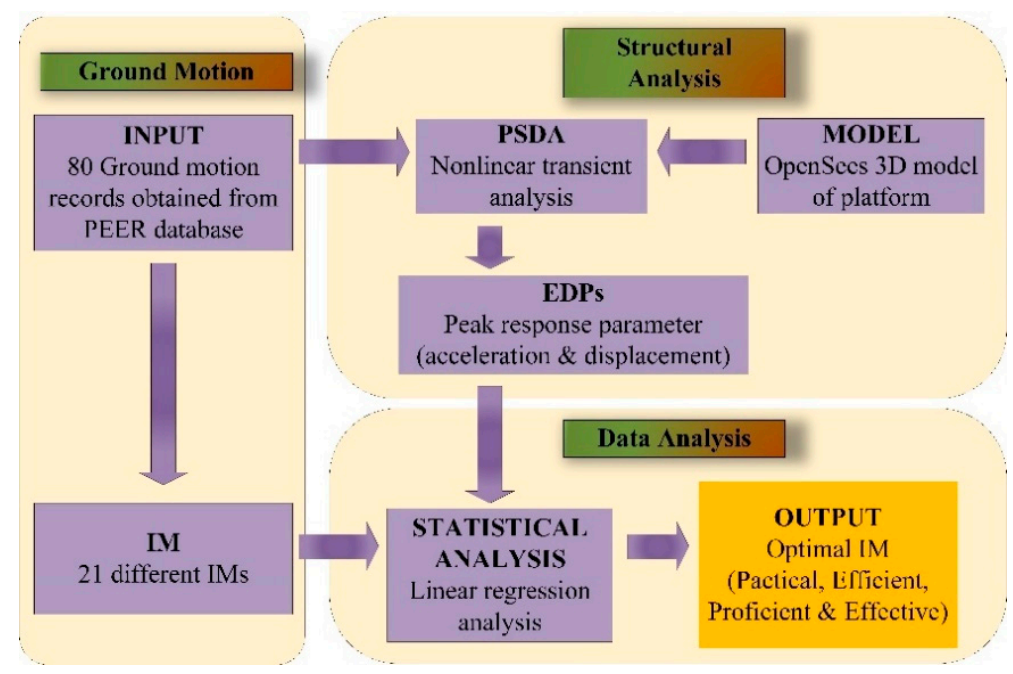

Figure 5. Outline of the methodology of optimal PSDM evaluation.

The selection of an approximate IM plays a vital role in reducing the deviation of seismic structural performances and predicting the responses of the structures more accurately. Four different criteria have been typically used to justify the optimality of any IM. Figure 6 shows the characteristics of selecting optimal IM in brief.

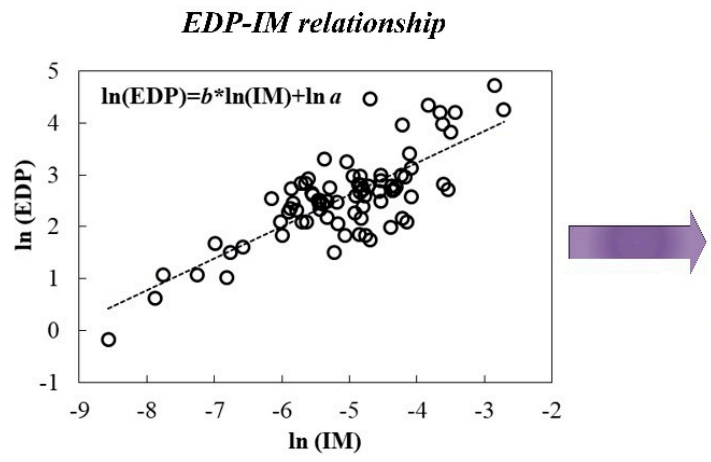

\section{Criteria for selecting an optimal IM}

Practicality comparison: $\boldsymbol{b}$, in Equation (2)

Efficiency comparison: $\boldsymbol{\beta}_{D|| M}$, in Equation (3)

Proficiency comparison: $\zeta$, in Equation (4)

Effectiveness comparison: $\boldsymbol{R}^{2}$, in Equation (5)

Figure 6. Optimal IM selection criteria.

\subsection{Practicality}

Practicality, introduced by Mackie et al. [54], indicates the direct relationship of the demand of structure on the IM, which is measured by the regression parameter $b$ in Equation (2). Values to zero illustrate that the IM has a negligible effect on demand estimation representing an impractical IM. On the contrary, higher values of $b$ imply a more practical IM.

\subsection{Efficiency}

Efficiency is known as the commonly used matric in identifying an optimal IM. An efficient IM can reduce the variability of the estimated demand median. The measure used to evaluate the efficiency is the dispersion, $\beta_{D \mid I M}$ in Equation (3), defined as the standard deviation of the logarithm of the demand model residuals. The lower dispersion value demonstrates higher efficiency for an IM. 


\subsection{Proficiency}

Proficiency, proposed by Padgett et al. [13], is a criterion that represents the composite effects of both efficiency and practicality. Lower values of $\zeta$ indicate more proficiency in IMs. Proficiency, $\zeta$ can be defined in Equation (4) as follows:

$$
\zeta=\frac{\beta_{D \mid I M}}{b}
$$

\subsection{Effectiveness}

Effectiveness can be represented as the coefficient of determination, $R^{2}$, [55] refers to the percentage of the data closest to the regression line (the best-fitted line). The closer the $R^{2}$ value is to unity, the more effective the regression model is. The value of $R^{2}$ can be calculated by following:

$$
R^{2}=\left(\frac{n\left(\sum x_{i} y_{i}\right)-\left(\sum x_{i}\right)\left(\sum y_{i}\right)}{\sqrt{\left[n \sqrt{x_{i}{ }^{2}}-\left(\sum x_{i}\right)^{2}\right]\left[n \sqrt{y_{i}{ }^{2}}-\left(\sum y_{i}\right)^{2}\right]}}\right)^{2}
$$

where $n$ is the number of analysis data, and $x_{i}$ and $y_{i}$ are the results of the IMs and structural demand data, respectively.

\section{Result and Discussion}

Recalling the characteristics of an optimal IM described in Section 4, an optimal IM can be differentiated by higher values of slope $(b)$ and correlation coefficient $\left(R^{2}\right)$, whereas

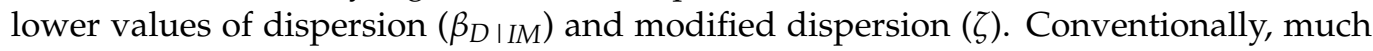
research illustrated that the demand of the structures follows a linear function of the IM in normal log space; therefore, PSDMs are generally determined by fitting a linear regression to the database in normal log space.

\subsection{Practicality Comparison}

The practicality of IMs can be represented by the regression parameter $b$, slope of the PSDM in Equation (2). A larger value of $b$ refers to a more practical IM. The practicality comparison of different IMs considering different Demand Parameters (max acceleration and max displacement of the structure) is illustrated in Figure 7. The figure shows that $A_{\text {rms }}$ tend to be the most practical IM while considering max acceleration as demand parameter, with the five most practical IMs being $\mathrm{A}_{\mathrm{rms}}>\mathrm{EDA}>\mathrm{PGA}>\mathrm{ASI}>\mathrm{A} 95$. The corresponding values $b$ are $1.021,0.971,0.97,0.968$, and 0.967 respectively. These five most practical IMs are acceleration-related IMs.

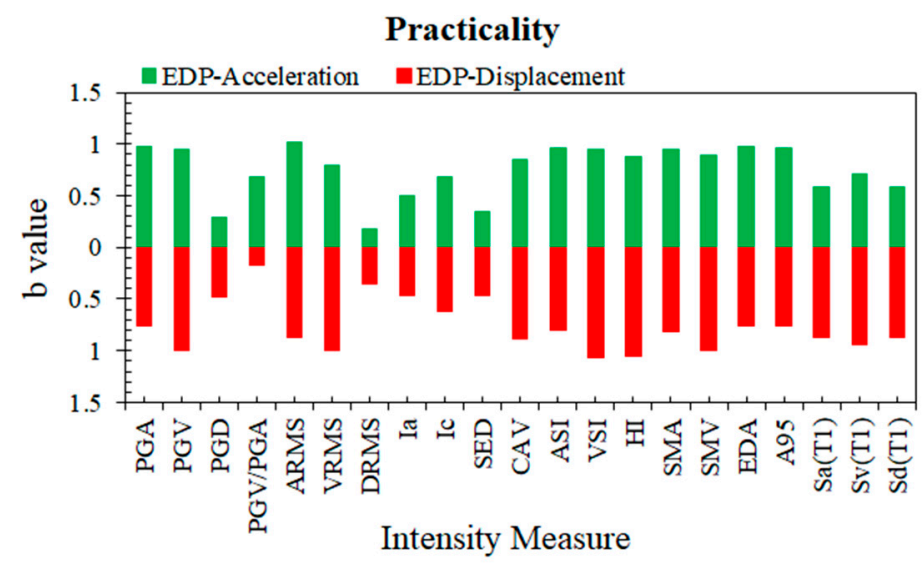

Figure 7. Practicality comparison. 
On the contrary, VSI turns out to be the most practical IM while considering max displacement as demand parameter, followed by $\mathrm{HI}, \mathrm{SMV}, \mathrm{V}_{\mathrm{rms}}$, and PGV. Interestingly, all of these five IMs are velocity-type IMs. Moreover, it needs to be mentioned that whether max acceleration or displacement is considered EDP, $\mathrm{D}_{\mathrm{rms}}$, and PGD are the two least practical IMs that are displacement-type IMs.

\subsection{Efficiency Comparison}

The efficiency of the IMs can be gauged by comparing the dispersion $\beta_{D \text { IIM }}$ obtained from the PSDMs shown in Equation (3). The lower value of dispersion, the more efficient IM is. While considering max acceleration as demand parameter, EDA, A95, PGA, ASI and SMA are considered more efficient measures since they have lesser dispersion $\beta_{D \mid I M}$ (Figure 8) than other IMs and all of these top five IMs are acceleration-type IMs. EDA, A95, and PGA are the three most efficient IMs with the value of dispersion $0.247,0.254$, and 0.256 , respectively.

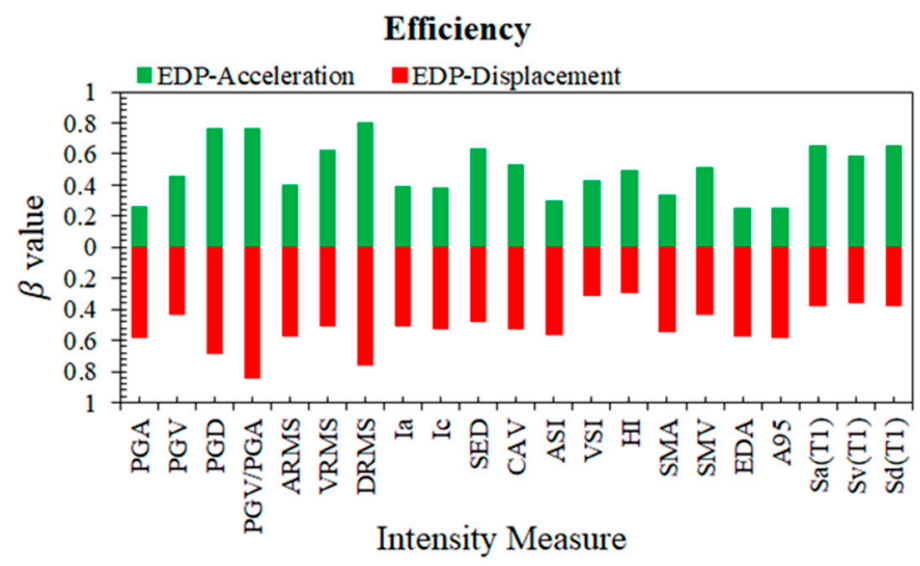

Figure 8. Efficiency comparison.

However, $\mathrm{HI}>\mathrm{VSI}>S_{v}\left(T_{1}\right)>S_{a}\left(T_{1}\right)>S_{d}\left(T_{1}\right)>\mathrm{PGV}>$ SMV top the ranking of the most efficient while considering max displacement as EDP. Apart from $S_{a}\left(T_{1}\right)$ and $S_{d}\left(T_{1}\right)$, all are velocity-type IMs. HI and VSI are the two most efficient IMs (max disp. as EDP) with 0.290 and 0.312 , respectively. $\mathrm{D}_{\mathrm{rms}}, \mathrm{PGD}$ and PGV/PGA are the three least efficient IMs for both cases of EDP. Two of them, PGD and $D_{\text {rms }}$ are displacement-related IMs.

\subsection{Proficiency Comparison}

The composite measure $\zeta$ can be assessed to evaluate the proficiency of IMs, which combines practicality and efficiency, shown in Equation (4). Smaller values of $\zeta$ refer to more proficient IMs. Figure 9 summarizes the proficiency of IMs where acceleration-type IMs perform well considering max acceleration as EDP. The top five proficient IMs are EDA $>$ A95 $>$ PGA $>$ ASI $>$ SMA. The values of $\zeta$ concerning EDA, A95, and PGA are 0.255, 0.262 , and 0.264 , respectively.

Contrastingly HI, VSI, $S_{v}\left(T_{1}\right), S_{a}\left(T_{1}\right), S_{d}\left(T_{1}\right), \mathrm{PGV}, \mathrm{SMV}$, and $\mathrm{V}_{\mathrm{rms}}$ top the order of the most proficient IMs in case of max displacement as EDP. All of these IMs are velocityrelated IMs except $S_{a}\left(T_{1}\right)$ and $S_{d}\left(T_{1}\right)$. Finally, two displacement-type IMs, PGD and $\mathrm{D}_{\mathrm{rms}}$ are the two least proficient IMs for both EDP. 


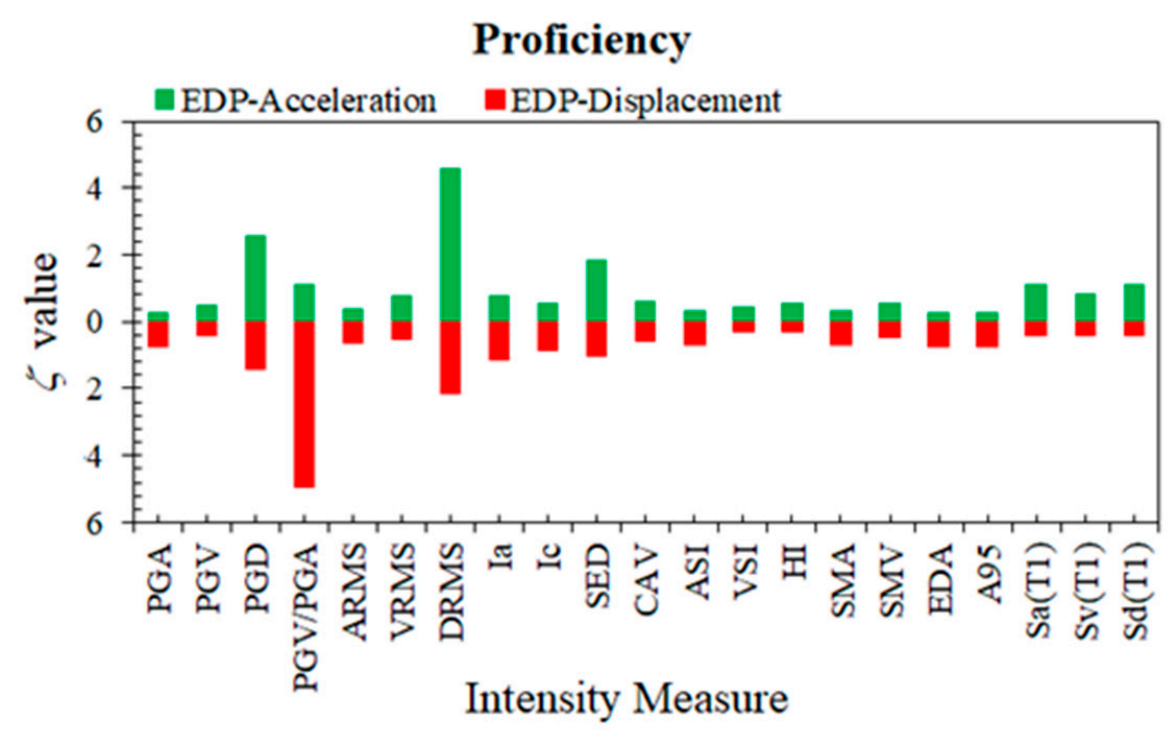

Figure 9. Proficiency comparison.

\subsection{Effectiveness Comparison}

The effectiveness illustrates how well the regression model of Equation (5) fits the seismic demand. This can be described as the correlation coefficient $R^{2}$ value ranging from 0 to 1 . A larger $R^{2}$ indicates a better correlation relationship between the demand parameter and IM. Figures 10 and 11 illustrate the linear regression analysis of PSDMs with respect to different IMs considering two cases of EDPs (max acceleration and max displacement). Figure 10 shows that peak acceleration of PSDMs with respect to EDA, A95, PGA, ASI, and SMA have significantly higher $R^{2}$ values than others containing the values of $0.9098,0.9049$, $0.9033,0.8732$, and 0.8374 , respectively. This implies that the scattering of PSDMs using the abovementioned IMs is much smaller than that of others. Figure 11 illustrates that HI, VSI, $S_{v}\left(T_{1}\right), S_{a}\left(T_{1}\right)$, and $S_{d}\left(T_{1}\right)$, with the $R^{2}$ values of $0.882,0.8633,0.8172,0.8063$, and 0.8048 , respectively, are the top five strongly correlated IMs while considering peak displacement as EDP. From Figure 10, the values of correlation coefficients are within a range of 0.9098 to 0.0522, while Figure 11 shows the range of coefficient is from 0.882 to 0.0077 .

As illustrated in Figure 12, for the case of max acceleration as EDP, EDA, with the value of 0.91 , proves to be the most effective one, followed by acceleration-type IMs such as A95, PGA, ASI, and SMA.

Furthermore, the order of the top effective IMs is HI $>$ VSI $>S_{v}\left(T_{1}\right)>S_{a}\left(T_{1}\right)>S_{d}\left(T_{1}\right)$ $>$ PGV $>$ SMV $>$ SED since they correspond to larger values of $R^{2}$ while max displacement is considered as EDP. Excluding $S_{a}\left(T_{1}\right)$ and $S_{d}\left(T_{1}\right)$, all are velocity-type IMs. Moreover, PGV/PGA, along with two displacement-type IMs, $D_{\text {rms }}$ and PGD prove to be the three weakest correlated IMs for both EDPs.

A table of different IMs and four types of coefficient values is provided in Appendix A. The top five or six IMs in terms of four criteria are indicated with boldfaces. 

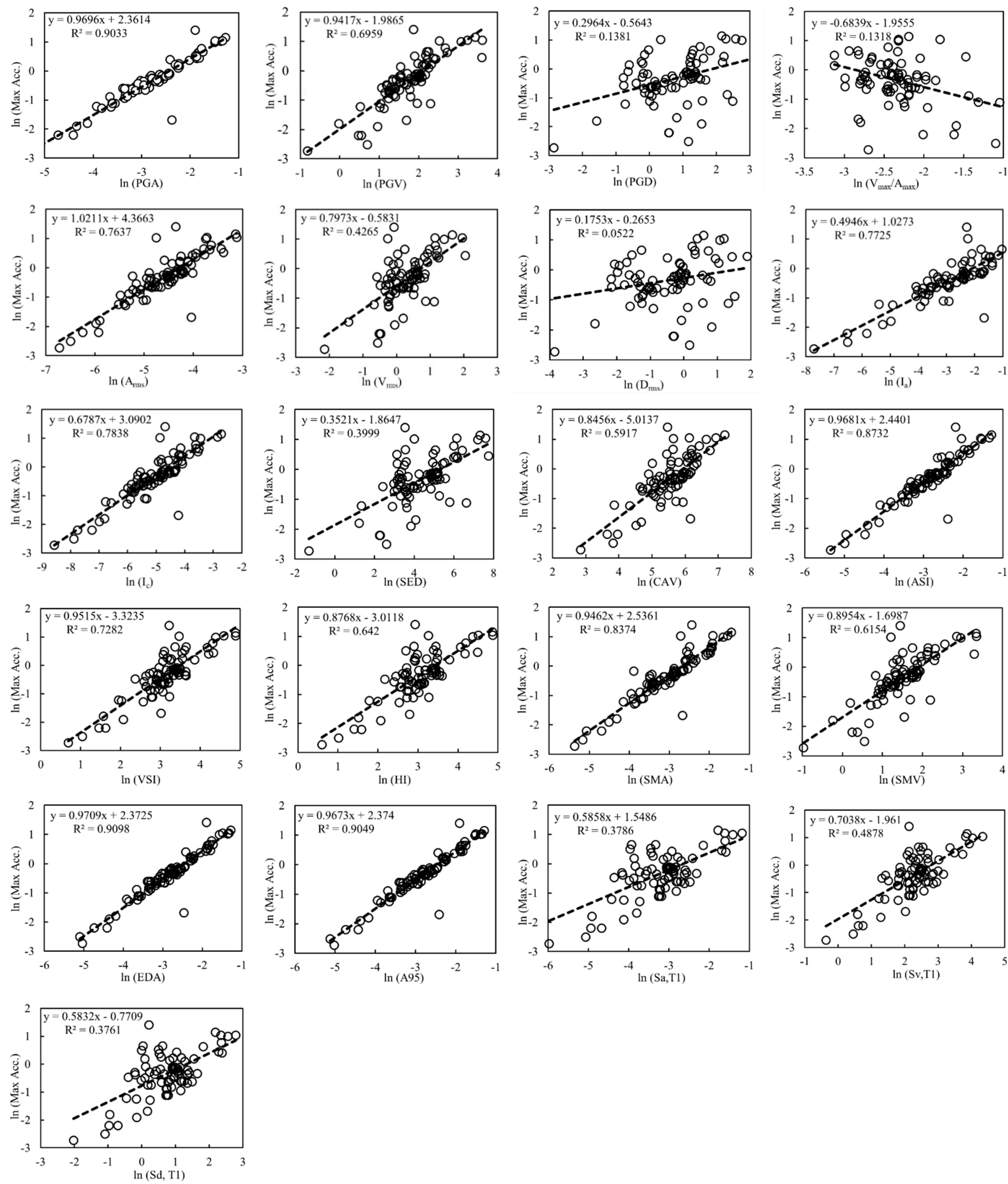

Figure 10. Linear regression of PSDMs for various IMs considering maximum acceleration as EDP. 

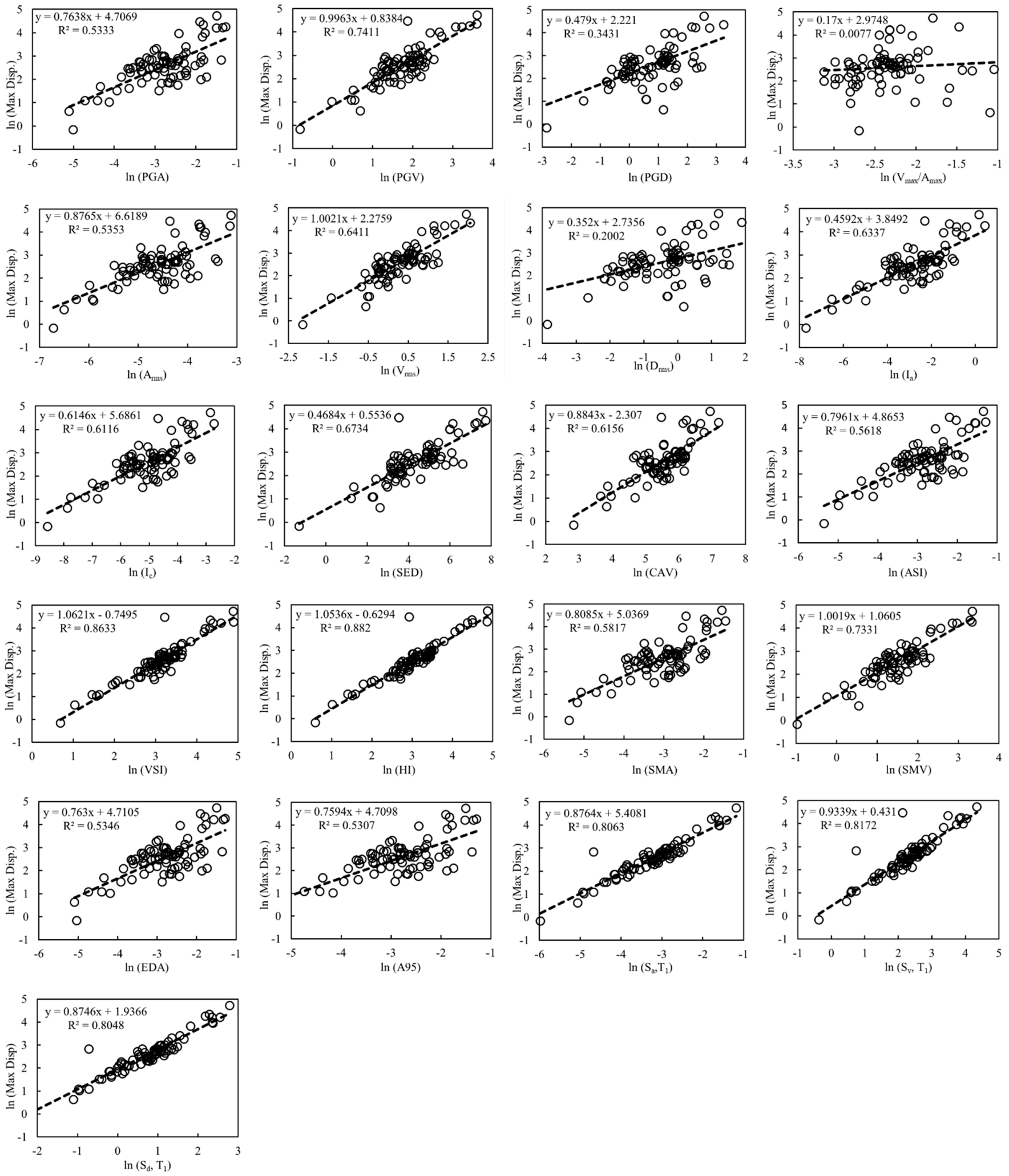

Figure 11. Linear regression of PSDMs for various IMs considering maximum displacement as EDP. 


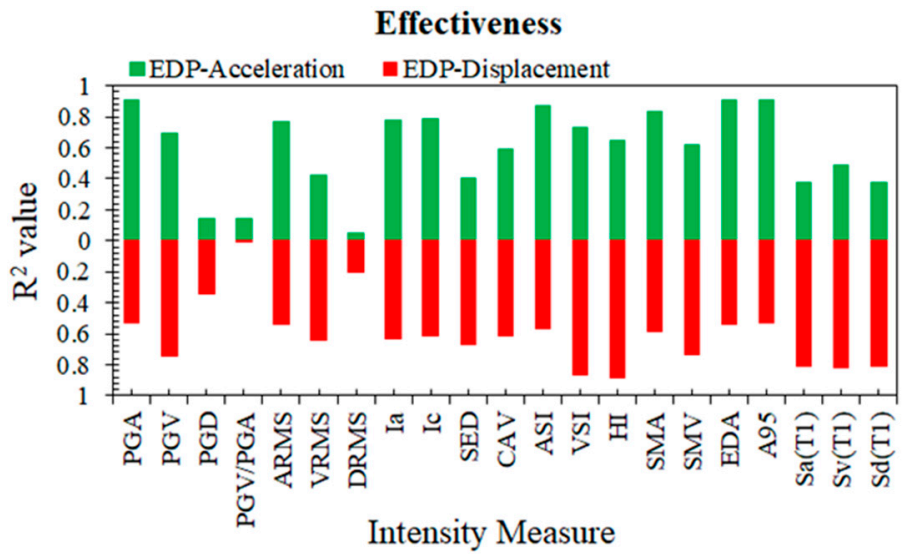

Figure 12. Effectiveness comparison.

\section{Conclusions}

The significant optimal intensity measure for offshore jacket platforms that can be used in the seismic probabilistic risk assessments is investigated in this research. A finite element model is developed using OpenSees and validated the model based on previous studies. Two demand parameters; peak acceleration and displacement are considered and obtained from nonlinear time history analysis. Linear regression analysis is performed to observe the correlation between IMs and demand parameters considering four significant indicators: efficiency, proficiency, practicality, and effectiveness. The summarization of the present study is:

1. The significant IMs (EDA, A95, and PGA) are unrelated to the damping ratio, which is more rational for such structures.

2. As an offshore platform is a mass-sensitive structure and the inertia force influences the performance of selection criteria, the optimality of IM depends on the structure's demand parameter.

3. Based on comparing practicality, efficiency, proficiency, and effectiveness, accelerationtype IMs, i.e., EDA, A95, PGA, are the most optimal IMs because these IMs rank top consistently in all criteria considering maximum acceleration as the demand parameter of the structure. In case of maximum acceleration as EDP, the seismic response of an offshore platform is sensitive to acceleration rather than velocity or displacement.

4. Velocity-type IMs, i.e., HI and VSI, are the two most optimal IMs in all selected categories of optimal IM when maximum displacement as EDP is considered. The platform's response is reactive to velocity instead of acceleration or displacement if the EDP is maximum displacement.

5. A significant IM can improve the accuracy of the computation of seismic performance analysis. For offshore platforms, EDA and A95 parameter perform better than PGA and $S_{a}$. Moreover, these IMs (EDA and A95) are structure-independent and thus becoming irrelative to the damping ratio.

6. For both cases of peak acceleration and displacement as EDPs, displacement-type IMs $\left(\mathrm{PGD}, \mathrm{D}_{\mathrm{rms}}\right)$ are the weakest or least significant IMs subjected to the seismic demand of an offshore platform.

Author Contributions: Conceptualization, S.S.; Methodology, S.S.; Software, S.S.; FEM model and its validation, S.S., M.S.A., and C.S.; Formal analysis, S.S.; Investigation, S.S.; Writing-original draft preparation, S.S.; Writing—review and editing of final draft, S.S., D.K., M.S.A., C.S., and S.G.; Project administration, D.K.; Supervision, D.K.; Funding acquisition, D.K. All authors have read and agreed to the published version of the manuscript. 
Funding: This research was supported by the National Research Foundation of Korea (NRF) grant funded by the Korean government (MSIT) (2018R1A2B2005519). It was also supported by the National University Development Project by the Ministry of Education in 2021.

Institutional Review Board Statement: Not applicable.

Informed Consent Statement: Not applicable.

Data Availability Statement: Some data that support the findings of this study are available from the corresponding author upon reasonable request.

Conflicts of Interest: The authors declare no conflict of interest.

\section{Appendix A}

The top five or six IMs in terms of different matrices are indicated in this demand models and IM comparisons with boldfaces.

\begin{tabular}{|c|c|c|c|c|c|c|c|c|c|}
\hline & & $R^{2}$ & $\beta$ & $b$ & $\zeta$ & $R^{2}$ & $\beta$ & $b$ & $\zeta$ \\
\hline IM Type & IM & \multicolumn{4}{|c|}{ EDP: Max Acceleration } & \multicolumn{4}{|c|}{ EDP: Max Displacement } \\
\hline \multirow{10}{*}{$\begin{array}{c}\text { Acceleration- } \\
\text { related }\end{array}$} & PGA & 0.903 & 0.256 & 0.970 & 0.264 & 0.533 & 0.576 & 0.764 & 0.754 \\
\hline & CAV & 0.592 & 0.526 & 0.846 & 0.622 & 0.616 & 0.523 & 0.884 & 0.591 \\
\hline & $\mathrm{I}_{\mathrm{a}}$ & 0.773 & 0.392 & 0.495 & 0.793 & 0.634 & 0.510 & 0.459 & 1.111 \\
\hline & $\mathrm{I}_{\mathrm{C}}$ & 0.784 & 0.382 & 0.679 & 0.563 & 0.612 & 0.526 & 0.615 & 0.855 \\
\hline & $\mathrm{A}_{\mathrm{rms}}$ & 0.764 & 0.400 & 1.021 & 0.392 & 0.535 & 0.575 & 0.877 & 0.656 \\
\hline & SMA & 0.837 & 0.332 & 0.947 & 0.350 & 0.582 & 0.545 & 0.809 & 0.675 \\
\hline & EDA & 0.910 & 0.247 & 0.971 & 0.255 & 0.535 & 0.575 & 0.763 & 0.754 \\
\hline & A95 & 0.905 & 0.254 & 0.967 & 0.262 & 0.531 & 0.578 & 0.759 & 0.761 \\
\hline & ASI & 0.873 & 0.293 & 0.968 & 0.303 & 0.562 & 0.558 & 0.796 & 0.701 \\
\hline & $S_{a}\left(T_{1}\right)$ & 0.379 & 0.648 & 0.586 & 1.107 & 0.806 & 0.371 & 0.876 & 0.423 \\
\hline \multirow{7}{*}{ Velocity-related } & PGV & 0.696 & 0.454 & 0.942 & 0.482 & 0.741 & 0.429 & 0.996 & 0.431 \\
\hline & $\mathrm{V}_{\mathrm{rms}}$ & 0.427 & 0.623 & 0.797 & 0.781 & 0.641 & 0.505 & 1.002 & 0.504 \\
\hline & SED & 0.400 & 0.637 & 0.352 & 1.810 & 0.673 & 0.482 & 0.468 & 1.029 \\
\hline & SMV & 0.615 & 0.510 & 0.895 & 0.570 & 0.733 & 0.436 & 1.002 & 0.435 \\
\hline & $S_{v}\left(T_{1}\right)$ & 0.488 & 0.589 & 0.704 & 0.836 & 0.817 & 0.361 & 0.934 & 0.386 \\
\hline & $\mathrm{HI}$ & 0.642 & 0.492 & 0.877 & 0.561 & 0.882 & 0.290 & 1.054 & 0.275 \\
\hline & VSI & 0.728 & 0.429 & 0.952 & 0.451 & 0.863 & 0.312 & 1.062 & 0.294 \\
\hline \multirow{3}{*}{$\begin{array}{l}\text { Displacement- } \\
\quad \text { related }\end{array}$} & PGD & 0.138 & 0.764 & 0.296 & 2.576 & 0.343 & 0.683 & 0.479 & 1.427 \\
\hline & $\mathrm{D}_{\mathrm{rms}}$ & 0.052 & 0.801 & 0.175 & 4.568 & 0.200 & 0.754 & 0.352 & 2.142 \\
\hline & $S_{d}\left(T_{1}\right)$ & 0.376 & 0.650 & 0.583 & 1.114 & 0.805 & 0.373 & 0.875 & 0.426 \\
\hline Time-related & $\mathrm{V} / \mathrm{A}$ & 0.138 & 0.764 & 0.684 & 1.117 & 0.008 & 0.840 & 0.170 & 4.941 \\
\hline
\end{tabular}

The illustration of all IM parameters of a ground motion is provided below:

\begin{tabular}{cc}
\hline IM (Unit) & Value \\
\hline PGA (g) & 0.151 \\
PGV (cm/s) & 8.866 \\
PGD (cm) & 3.599 \\
PGV /PGA (s) & 0.059 \\
ARMS (g) & 0.034 \\
VRMS (cm/s) & 2.535 \\
DRMS (cm) & 1.397 \\
Ia (m/s) & 0.388 \\
Ic & 0.029 \\
\hline
\end{tabular}




\begin{tabular}{cc}
\hline SED $\left(\mathrm{cm}^{2} / \mathrm{s}\right)$ & 141.353 \\
CAV $(\mathrm{cm} / \mathrm{s})$ & 486.707 \\
ASI $\left(\mathrm{g}^{*} \mathrm{~s}\right)$ & 0.159 \\
VSI $(\mathrm{cm})$ & 37.093 \\
HI $(\mathrm{cm})$ & 29.624 \\
SMA $(\mathrm{g})$ & 0.138 \\
SMV $(\mathrm{cm} / \mathrm{s})$ & 8.435 \\
EDA $(\mathrm{g})$ & 0.150 \\
A95 $(\mathrm{g})$ & 0.149 \\
$S_{a}, T_{1}(\mathrm{~g})$ & 0.032 \\
$S_{v}, T_{1}(\mathrm{~cm} / \mathrm{s})$ & 11.865 \\
$S_{d}, T_{1}(\mathrm{~cm})$ & 1.646 \\
\hline
\end{tabular}

\section{References}

1. Abdel Raheem, S.; Abdel Aal, E.; Abdel Shafy, A.; Fahmy, M.; Omar, M.; Mansour, M. In-place analysis for design-level assessment of the fixed offshore platform. Ships Offshore Struct. 2020, 16, 892-903. [CrossRef]

2. Jin, Q.; Li, X.; Sun, N.; Zhou, J.; Guan, J. Experimental and numerical study on tuned liquid dampers for controlling earthquake response of jacket offshore platform. Marine Struct. 2007, 20, 238-254. [CrossRef]

3. Tian, X.; Wang, Q.; Liu, G.; Liu, Y.; Xie, Y.; Deng, W. Topology optimization design for offshore platform jacket structure. Appl. Ocean Res. 2019, 84, 38-50. [CrossRef]

4. Konstandakopoulou, F.; Konstantinidou, M.; Pnevmatikos, N.; Hatzigeorgiou, G. Safety and Performance of Offshore Platforms Subjected to Repeated Earthquakes. Infrastructures 2020, 5, 38. [CrossRef]

5. Nielson, B.; DesRoches, R. Seismic fragility methodology for highway bridges using a component level approach. Earthq. Eng. Struct. Dyn. 2007, 36, 823-839. [CrossRef]

6. Muntasir Billah, A.; Shahria Alam, M. Seismic fragility assessment of highway bridges: A state-of-the-art review. Struct. Infrastruct. Eng. 2014, 11, 804-832. [CrossRef]

7. Kostinakis, K.; Fontara, I.; Athanatopoulou, A. Scalar Structure-Specific Ground Motion Intensity Measures for Assessing the Seismic Performance of Structures: A Review. J. Earthq. Eng. 2017, 22, 630-665. [CrossRef]

8. Zhang, Y.; Ding, Y.; Pang, Y. Selection of Optimal Intensity Measures in Seismic Damage Analysis of Cable-Stayed Bridges Subjected to Far-Fault Ground Motions. J. Earthq. Tsunami 2015, 9, 1550003. [CrossRef]

9. Liang, C.; Chen, J.; Xu, Q.; Li, J. Correlation Study between Seismic Intensity Measures and Nonlinear Response of Arch Dam via Endurance Time Analysis. KSCE J. Civ. Eng. 2020, 25, 256-271. [CrossRef]

10. Ghimire, S.; Guéguen, P.; Astorga, A. Analysis of the efficiency of intensity measures from real earthquake data recorded in buildings. Soil Dyn. Earthq. Eng. 2021, 147, 106751. [CrossRef]

11. Pejovic, R. Optimal intensity measures for probabilistic seismic demand models of RC high-rise buildings. Earthq. Struct. 2017, 13, 221-230.

12. Kostinakis, K.; Athanatopoulou, A.; Morfidis, K. Correlation between ground motion intensity measures and seismic damage of 3D R/C buildings. Eng. Struct. 2015, 82, 151-167. [CrossRef]

13. Padgett, J.; Nielson, B.; DesRoches, R. Selection of optimal intensity measures in probabilistic seismic demand models of highway bridge portfolios. Earthq. Eng. Struct. Dyn. 2008, 37, 711-725. [CrossRef]

14. Jiang, L.; Zhong, J.; He, M.; Yuan, W. Optimal Seismic Intensity Measure Selection for Isolated Bridges under Pulse-Like Ground Motions. Adv. Civ. Eng. 2019, 2019, 3858457. [CrossRef]

15. Dehghanpoor, A.; Thambiratnam, D.; Zhang, W.; Chan, T.; Taciroglu, E. An extended probabilistic demand model with optimal intensity measures for seismic performance characterization of isolated bridges under coupled horizontal and vertical motions. Bull. Earthq. Eng. 2021, 19, 2291-2323. [CrossRef]

16. Wei, B.; Hu, Z.; He, X.; Jiang, L. Evaluation of optimal ground motion intensity measures and seismic fragility analysis of a multi-pylon cable-stayed bridge with super-high piers in Mountainous Areas. Soil Dyn. Earthq. Eng. 2020, 129, 105945. [CrossRef]

17. O'Reilly, G. Seismic intensity measures for risk assessment of bridges. Bull. Earthq. Eng. 2021, 19, 3671-3699. [CrossRef]

18. Nguyen, D.; Lee, T.; Phan, V. Optimal Earthquake Intensity Measures for Probabilistic Seismic Demand Models of Base-Isolated Nuclear Power Plant Structures. Energies 2021, 14, 5163. [CrossRef]

19. Nguyen, D.; Thusa, B.; Han, T.; Lee, T. Identifying significant earthquake intensity measures for evaluating seismic damage and fragility of nuclear power plant structures. Nucl. Eng. Technol. 2020, 52, 192-205. [CrossRef]

20. Tsinidis, G.; Di Sarno, L.; Sextos, A.; Furtner, P. Optimal intensity measures for the structural assessment of buried steel natural gas pipelines due to seismically induced axial compression at geotechnical discontinuities. Soil Dyn. Earthq. Eng. 2020, 131, 106030. [CrossRef]

21. Shakib, H.; Jahangiri, V. Intensity measures for the assessment of the seismic response of buried steel pipelines. Bull. Earthq. Eng. 2016, 14, 1265-1284. [CrossRef]

22. Hariri-Ardebili, M.; Saouma, V. Probabilistic seismic demand model and optimal intensity measure for concrete dams. Struct. Saf. 2016, 59, 67-85. [CrossRef] 
23. Li, Z.; Wu, Z.; Lu, X.; Zhou, J.; Chen, J.; Liu, L.; Pei, L. Efficient seismic risk analysis of gravity dams via screening of intensity measures and simulated non-parametric fragility curves. Soil Dyn. Earthq. Eng. 2021, 152, 107040. [CrossRef]

24. Huang, Z.; Pitilakis, K.; Argyroudis, S.; Tsinidis, G.; Zhang, D. Selection of optimal intensity measures for fragility assessment of circular tunnels in soft soil deposits. Soil Dyn. Earthq. Eng. 2021, 145, 106724. [CrossRef]

25. Bakalis, K.; Kohrangi, M.; Vamvatsikos, D. Seismic intensity measures for above-ground liquid storage tanks. Earthq. Eng. Struct. Dyn. 2018, 47, 1844-1863. [CrossRef]

26. Babaei, S.; Amirabadi, R.; Sharifi, M. Evaluation of Optimal IM-EDP pairs for Typical South Pars Fixed Pile-Founded Offshore Platforms. Intl. J. Marit. Technol. 2021, 15, 29-49.

27. Babaei, S.; Amirabadi, R.; Sharifi, M.; Ventura, C. Optimal probabilistic seismic demand model for fixed pile-founded offshore platforms considering soil-pile-structure interaction. Structures 2021, 33, 4330-4343. [CrossRef]

28. Vazirizade, S.; Azizsoltani, H.; Haldar, A. Reliability estimation of jacket type offshore platforms against seismic and wave loadings applied in time domain. Ships Offshore Struct. 2020, 1-10. [CrossRef]

29. Abyani, M.; Bahaari, M.; Zarrin, M.; Nasseri, M. Effects of sample size of ground motions on seismic fragility analysis of offshore jacket platforms using Genetic Algorithm. Ocean Eng. 2019, 189, 106326. [CrossRef]

30. Zhao, S.; Bi, C.; Sun, Z. Engineering analysis of the dynamic characteristics of an electrical jacket platform of an offshore wind farm under seismic loads. Appl. Ocean Res. 2021, 112, 102692. [CrossRef]

31. Konstandakopoulou, F.; Papagiannopoulos, G.; Pnevmatikos, N.; Hatzigeorgiou, G. Seismic Hazard Assessment of Offshore Platforms. Intl. J. Civ. Environ. Eng. 2019, 13, 272-276.

32. Zarrin, M.; Mostafa Gharabaghi, A.; Poursha, M. A multi-mode N2 (MN2) pushover procedure for ductility level seismic performance evaluation of jacket type offshore platforms. Ocean Eng. 2021, 220, 108440. [CrossRef]

33. Dastan Diznab, M.; Mehdigholi, H.; Seif, M. Seismic performance assessment of fixed offshore structures by endurance time method. Ships Offshore Struct. 2019, 14, 709-722. [CrossRef]

34. Bezir, F.; Cicek, K.; Sari, A. Seismic Fragility Analysis of Jacket Type Offshore Structures. In Proceedings of the International Conference on Earthquake Engineering and Seismology (5ICEES), Ankara, Turkey, 8-11 October 2019; Volume 8, p. 11.

35. Regenhardt, T.; Azad, M.; Punurai, W.; Beer, M. A Novel Application of System Survival Signature in Reliability Assessment of Offshore Structures. In Advances in Intelligent Systems and Computing. Proceedings of the International Conference on Intelligent Computing E Optimization; Vasant, P., Zelinka, I., Weber, G.W., Eds.; Springer: Cham, Switzerland, 2018; Volume 866, pp. 11-20.

36. Behrensdorf, J.; Azad, M.; Broggi, M.; Punurai, W.; Beer, M. Reliability based optimization of inspection and maintenance schedules for offshore jacket structures subject to marine corrosion. In Proceedings of the Seventh Asian-Pacific Symposium on Structural Reliability and Its Applications (APSSRA2020), Tokyo, Japan, 4-7 October 2020.

37. Recommended Practice for Planning, Designing, and Constructing Fixed Offshore Platforms, 21st ed.; American Petroleum Institute: Washington, DC, USA, 2000.

38. Yue, Q.; Zhang, L.; Zhang, W.; Kärnä, T. Mitigating ice-induced jacket platform vibrations utilizing a TMD system. Cold Regions Sci. Technol. 2009, 56, 84-89. [CrossRef]

39. Mazzoni, S.; McKenna, F.; Scott, M.H.; Fenves, G.L. OpenSees Command Language Manual; Pacific Earthquake Engineering Research (PEER) Center: Berkeley, UC, USA, 2006; p. 264.

40. Azad, M.; Punurai, W.; Sinsabvarodom, C.; Asavadorndeja, P. Effects of Redundancy in Bracing Systems on the Fragility Curve Development of Steel Jacket Offshore Platform. Eng. J. 2019, 23, 123-133. [CrossRef]

41. Punurai, W.; Azad, M.; Pholdee, N.; Bureerat, S.; Sinsabvarodom, C. A novel hybridized metaheuristic technique in enhancing the diagnosis of cross-sectional dent damaged offshore platform members. Comput. Intell. 2019, 36, 132-150. [CrossRef]

42. Nour El-Din, M.; Kim, J. Seismic performance of pile-founded fixed jacket platforms with chevron braces. Struct. Infrastruct. Eng. 2014, 11, 776-795. [CrossRef]

43. PEER Ground Motion Database-PEER Center. Available online: https://ngawest2.berkeley.edu/ (accessed on 8 July 2021).

44. Kramer, S.L. Geotechnical Earthquake Engineering; Prentice Hall. Inc.: Upper Saddle River, NJ, USA, 1996.

45. Reed, J.; Kassawara, R. A criterion for determining exceedance of the operating basis earthquake. Nucl. Eng. Des. 1990, 123, 387-396. [CrossRef]

46. Arias, A. A Measure of Earthquake Intensity. In Seismic Design for Nuclear Power Plants; Hansen, R.J., Ed.; MIT Press: Cambridge MA, USA, 1970; pp. 438-483.

47. Park, Y.; Ang, A.; Wen, Y. Seismic Damage Analysis of Reinforced Concrete Buildings. J. Struct. Eng. 1985, 111, 740-757. [CrossRef]

48. Housner, G.; Jennings, P. Generation of Artificial Earthquakes. J. Eng. Mech. Div. 1964, 90, 113-150. [CrossRef]

49. Nuttli, O.W. The Relation of Sustained Maximum Ground Acceleration and Velocity to Earthquake Intensity and Magnitude; US Army Engineer Waterways Experiment Station: Vicksburg, MS, USA, 1979.

50. Sarma, S.; Yang, K. An evaluation of strong motion records and a new parameter A95. Earthq. Eng. Struct. Dyn. 1987, 15, 119-132. [CrossRef]

51. Von, T.; Rochim, L.H.; Scott, G.A.; Wilson, J.A. Earthquake ground motions for design and analysis of dams. In Earthquake Engineering and Soil Dynamics II-Recent Advances in Ground-Motion Evaluation; Geotechnical Special Publication: Park City, UT, USA, 1988; Volume 20, pp. 463-481.

52. Housner, G. Behavior of Structures During Earthquakes. J. Eng. Mech. Div. 1959, 85, 109-129. [CrossRef] 
53. Cornell, C.; Jalayer, F.; Hamburger, R.; Foutch, D. Probabilistic Basis for 2000 SAC Federal Emergency Management Agency Steel Moment Frame Guidelines. J. Struct. Eng. 2002, 128, 526-533. [CrossRef]

54. Mackie, K.; Stojadinović, B. Probabilistic Seismic Demand Model for California Highway Bridges. J. Bridge Eng. 2001, 6, 468-481. [CrossRef]

55. Wang, X.; Shafieezadeh, A.; Ye, A. Optimal intensity measures for probabilistic seismic demand modeling of extended pile-shaftsupported bridges in liquefied and laterally spreading ground. Bull. Earthq. Eng. 2017, 16, 229-257. [CrossRef] 